\title{
The biological activity of bacterial vaccine of Pseudomonas putida2 and Pseudomonas fluorescens 3 isolates to protect sesame crop (Sesamum indicum) from Fusarium fungi under field conditions
}

\author{
Hammad Nawaf Farhan ${ }^{1}$, Basher H. Abdullah ${ }^{2}$ and. Ashwaq T. Hameed ${ }^{3}$ \\ ${ }^{1}$ Professor at Biology Department, College of Education for Pure Science, Al-Anbar University, \\ Iraq (E-mail: drhammad51@yahoo.com). \\ ${ }^{2}$ Dr. at Agronomy Department, College of Agriculture, Al-Anbar University, Iraq. \\ ${ }^{3}$ Lecturer at Biology Department, College of Science, Al-Anbar University, Iraq.
}

\begin{abstract}
This research investigated the biological effects of Pseudomonas putida2 and Pseudomonas fluorescens 3 as biocides to inhibit Fusarium fungi growth and as biofertilizers to improve growth characters of sesame crop grown in contaminated soil with Fusarium under field conditions compared with Dithen. Results showed mixture of vaccine Pseudomonas putida2 + Pseudomonas fluorescence 3 together was more effect on Fusarium growth and increased growth characters much higher than each isolate alone. Both isolates scored significant improving in morphological, physiological and productivity characters for sesame compared with control and Dithen treatments. But mixture of $P$. putida2 $+P$. fluorescens3 treatment together (Fusant) as a biocide and biofertilizers gave higher significant results in increasing chlorophyll content, percentage of $N, P, K$ in total dry weight of shoot, branch no./plant, height of plant, leaf area per plant, leaf no./plant, pods no./plant, grains no./pod, total weight of 1000 grains, total yield of grains/plot, and percentage of oil in sesame grains. The values were $3.21 \mathrm{mg} / \mathrm{gm}, 4.18 \%, 0.44 \%, 3.87 \%, 45.8 \mathrm{branch} / \mathrm{plant}$, $151.7 \mathrm{~cm} /$ plant, $59.7 \mathrm{~cm}^{2} /$ plant, 428.3 leaf/plant, $146.7 \mathrm{pod} /$ plant, $69.1 \mathrm{grain} / \mathrm{pod}, 2.92 \mathrm{gm} / 1000$ grain, $982.3 \mathrm{gm}$ (grains)/plot and $56.2 \%$ oil in sesame grains respectively. While control treatment scored: $0.85 \mathrm{mg} / \mathrm{gm}, 1.77 \%, 0.11 \%, 1.43 \%, 14.6$ branch/plant, $53.3 \mathrm{~cm} /$ plant, $25.5 \mathrm{~cm}^{2} /$ plant, 162.7 leaf/plant, $44.0 \mathrm{pod} / \mathrm{plant}, 31.3 \mathrm{grain} / \mathrm{pod}, 0.94 \mathrm{gm} / 1000 \mathrm{grain}, 112.4 \mathrm{gm}$ (grains)/plot and $26.6 \%$ oil in sesame grains respectively.
\end{abstract}

Keywords: Biological Control, Pseudomonas Bacteria, Fusarium Fungi, Sesame Crop.

\section{INTRODUCTION}

Sesame crop is one of the important and strategic oil crops in the world. It has an economical importance to produce plant oil. Unfortunately, In Iraq, there are a lot of problems facing sesame agriculture like wilting disease, root rot and damping off for seedlings, which happen by some fungus which transfer from soil to the plant to infect the crop. Fusarium is one of these fungi. Infection by Fusarium fungi causes: 1) high reduction in germination percentage because the high reduction in embryo activity of seeds by fungus; (2) seedlings death at the first stage of growth; (3) death of the whole plant at flowering stage; and finally (4) reduction in production.

It has been estimated that total losses as a consequence of plant diseases reached $25 \%$ of the yield in western countries and almost $50 \%$ in developing countries, one third of this is due to fungal (Bowyer, 1999). Pseudomonas sp. can produce siderophores compounds which can inhibit growth of plant pathogenic fungi (Kumar \& Dube, 1992; Loper \& Henkel, 1999; Lottmann et al., 2000; Khan et al., 2006; Abdel-Salam et al., 2007). Other metabolites compounds with siderophores can produced by Pseudomonas sp isolates (Loper, 1988; Weller, 1988; Kumar \& Dube, 1992; Duijff et al, 1993; Dowling \& O,Gara, 1994; Loper \& Henkel, 1999; Lottmann et al., 2000). Moreover, most of Pseudomonas putida and Pseudomonas fluorescens and other species can produce phenozine antibiotic compound which inhibit growth of plant pathogenic fungi (Thomashow \& Weller, 1988). For example, Pseudomonas chlororaphis pcl 1391 inhibited successfully growth of Fusarium oxysporium which caused root rot for tomato crop (Chin et al., 1998). Pseudomonas isolates can also produce some antibiotic compounds which can inhibit fungi growth (Schroth \& Hancook, 1982). Many strains of $P$. fluorescens are known to enhance plant growth 
promotion and reduce severity of various diseases and induced systematic resistance, biological control of pathogens (Ganeshan and Kumar, 2005). Fusants between Pseudomonas fluorescens and Pseudomonas aeruginosa showed higher antagonistic efficiency reached three times more than the efficiency of $P$. fluorescens and two times more than efficiency of $P$. aeruginosa in controlling the plant pathogen Fusarium oxysporium (Abdel-Salam et al., 2007). There was a direct inhibition when Pseudomonas fluorescens used alone against Pythium aphanidermatum, with cowpea plants, and provided a reduction of the disease index from 3.44 to 1.06 (Nwaga et al., 2007). Pseudomonas spp seem to be the most successful Biocontrol agent against Pythium ultimum in a number of reports (Hadedorn et al., 1993 and Georgakopoulos et al., 2002).

The ability of pseudomonas $s p$. in stimulating germination and plant growth may be related to some compounds like plant hormones e.g. gibberellins, cytokines, Indole acetic acid (IAA) and polysaccharides (Deweger et al., 1987; Kloepper et al., 1992; Glick et al., 1997; and Abed et al., 2009). Indeed, fluorescent Pseudomonas belongs to plant growth promoting rhizobacteria (PGPR) (Ganeshan and Kumar, 2005). Using biofertilizers in the biological experiments increased the quantity and quality characters of plant when seeds treated with them (Burr et al., 1978; Hossain, 1987; Smith and Goodman, 1999; Hameed \& Farhan, 2007 and Abed et al., 2009). Many strains of Pseudomonas fluorescens, significantly reduced the extent of both wheat coleoptiles growth retardation and wheat and barley seedling blight caused by Fusarium culmorum by 53 - $91 \%$ (Khan et al., 2006). The effect of Pseudomonas $s p$ vaccines on germination, morphological and physiological characters of crops was studied by many researchers. Weller and Cook (1986) found increasing in growth and productivity of wheat when seeds treated with Pseudomonas fluorescens against Pythium fungi. While Deluz et al., (1998) found significant increasing in germination and productivity of wheat when seeds treated with Pseudomonas putida against fungi growth compared with untreated seeds. Hameed \& Farhan (2007) found significant higher values in growth and germination percentage of Sorghum bicolor crop compared with control treatment by using bacterial vaccines of Pseudomonas aureofaiciens \& Pseudomonas putida. The two isolates also improved growth characters of plants cultured in soil contaminated with Rhizoctonia solani fungi and significantly inhibited the effect of plant pathogen fungi.

The effects of Pseudomonas in improving other growth characters like leaf area, leaf number per plant and chlorophyll content were studied by many workers. Benani et al., (1994) found that Pseudomonas increased leaf area per plant by $30 \%$. Hameed \& Farhan (2007) found similar results, that $P$. aureofaiciens and $P$. putida increased leaf area per plant and chlorophyll content in sorghum plant significantly compared with control and fungi treatments. The ability of Pseudomonas $s p$ in increasing chlorophyll content in leaves may be related to supplying the plants with some nutrient elements like $\mathrm{N}$ and $\mathrm{P}$ (Hameed \& Farhan, 2007). Moreover, they showed significant increase in levels of nitrogen and phosphorus in total dry weight of shoot per plant for all plants which treated with bacterial vaccines compared with fungi treatments.

This research investigated the biological effects of some isolated bacteria from Iraqi soils like Pseudomonas putida2 and Pseudomonas fluorescens 3 as biocides to inhibit Fusarium fungi growth and as biofertilizers to increase and improve percentage of germination, productivity, morphological and physiological characters for sesame crop grown under field conditions.

\section{MATERIALS AND METHODS}

\section{Experiment no.1: The Biological Activity of Pseudomonas putida2 and Pseudomonas fluorescens 3 as biocide to inhibit Fusarium fungi growth comparison with Dithen and Radiomil Fungicide under incubator Conditions.}

King B (KB) medium was prepared to activate bacteria growth (Cowan, 1977). While, Potato Dextrose Agar (PDA) was prepared to activate fungi growth (Agrios, 1988). Autoclave used to sterilize culture media under $121 \mathrm{C}^{0}$, pressure $15 \mathrm{P} /$ inch for 15 minutes. Oven used to sterilize all glasses under 180 $\mathrm{C}^{0}$. Alcohol $70 \%$ was used to sterilize benches, tables, others. Bacteria isolates were supplied from Biology Department, College of Sciences, Al-Anbar University. While, Fusarium Sp isolate was supplied previously from Department of Plant Protection, College of Agriculture, Baghdad University to Biology Department, College of Sciences, Al-Anbar University. Isolated bacteria were activated in liquid media prepared from each isolated bacteria in conical flask size $250 \mathrm{ml}$, contains $100 \mathrm{ml}$ of KB liquid culture media, after contamination with bacteria each conical flask was incubated at $28 \mathrm{C}^{0}$ for 24 hours to activate 
the two isolates bacteria, and then were kept in the fridge at $4{ }^{\circ} \mathrm{C}$.

Small mycelium as a sample from Fusarium pathogenic fungi was cultured in sterilized Petridishes size $7 \mathrm{~cm}$ contain PDA culture media, then all dishes were incubated in the incubator at $25 \mathrm{C}^{0}$ to activate the growth of fungi for 24 hours. Fungi isolate was kept in the fridge at $4{ }^{\circ} \mathrm{C}$.

Solid media culture was used in sterilized Petri dishes size $9 \mathrm{~cm}$. Each Petri dish was contaminated completely with $0.1 \mathrm{ml}$ of bacterial vaccine by using sterilized pipette (Micropipette). Then small disc from Fusarium fungi was taken by cork borer, each $4 \mathrm{~mm}$ diameter. Each disc was cultured in the center of each Petri dish to test the inhibition activity of each isolated bacteria. All dishes were incubated in the incubator at $25 \mathrm{C}^{0}$ to activate the growth of fungi for 24 hours. Then fungi isolate was kept in the fridge at $4 \mathrm{C}^{0}$.

$0.5 \mathrm{gm}$ from Dithen and Radiomil GMZ68 chemical fungicide were taken and mixed separately well in 1 liter of sterilized and distilled water. Then $200 \mathrm{ml}$ from the mixture were put in sterilized conical flask size $500 \mathrm{ml}$ contain $\mathrm{KB}$ nutrient media, and mixed homogenously. After preparing media, it was dropped and distributed in sterilized Petri dishes size $9 \mathrm{~cm}$. All treatments were contaminated with $0.4 \mathrm{~cm}$ in diameter from Fusarium according to the experimental design. Control treatment was left without contamination with bacterial vaccine or chemical fungicides (Al-Amery, 2003). All Petri dishes were kept in the incubator at $28 \mathrm{C}^{0}$ for 7 days. Completely Randomized Design was used with three replicates in this experiment.

Pictures were taken for all treatments at the seventh day from the beginning of experiment (Fig. 1).

Inhibition percentage for fungi growth was calculated according to the following equation (Gamliel \& Katan, 1993):

Mean of fungi growth in control- mean of fungi growth in bacteria treatment

Inhibition \% = ------ $\times 100$

Mean of fungi growth in control treatment

Experiment no. 2: The Biological Activity of Bacterial Vaccine of Pseudomonas putida2 and Pseudomonas fluorescens3 Isolates to Protect Sesame Crop (Sesamum indicum) from Fusarium Fungi under Field Conditions.

Preparation of Biocide: Preparation of bacterial vaccines was similar to that described in Experiment 1. Wheat bran powder was used as a carrier for bacterial vaccine, it was prepared and dried well. Then, it sieved by sieve size 250 micrometer. Carrier was sterilized in the Autoclave at $121 \mathrm{C}^{0}$ for 30 minutes (Amer \& Utkhed, 2000). Under sterilized conditions inside Lab, Biocide was prepared for each isolate in concentration of $9 \log 10^{15} \mathrm{cfu} / 1 \mathrm{ml}$ in sterilized Petri dishes size $9 \mathrm{~cm}$, each contains $10 \mathrm{ml}$ of bacterial vaccine with $10 \mathrm{gm}$ from wheat bran powder. All dishes were kept under incubator conditions at $30 \mathrm{C}^{0}$ for 3 days to dry them gently (AlAmery, 2003). $1 \mathrm{ml}$ from each treatment was taken as a sample to test and count the total number of bacterial cells in $1 \mathrm{ml}$ under developed microscope as Clarks method (1965).

Dithen fungicide: Dithen fungicide was prepared as the following: $25 \mathrm{gm}$ from Dithen chemical fungicide mixed well in 1 liter of sterilized and distilled water. After preparing solution, it was dropped and distributed in the experimental plot soil according to the experimental design (Al-Amery, 2003).

Fusarium fungi activation: Fusarium fungi was cultured in Potato Dextrose Media (PDM) in Petri dishes size $9 \mathrm{~cm}$. Suspended solution of Fusarium fungi was prepared by adding $150 \mathrm{ml}$ from distilled and sterilized water to one Petri dish which contains fungi only. Electrical mixer was used for this purpose. This fungi mixture was added to the plots soil in depth of $5 \mathrm{~cm}$ three days before planting (on $12^{\text {th }}$ May, 2009) according to the experimental design (AlAmery, 2003).

Preparing of Sesame seeds: Sesame seeds from local variety were sterilized by sodium hypo chloride $1 \%$ for 3 minutes, and washed gently by sterilized and distilled water then dried well (Beckker \& Cook, 1988). Seeds were soaked in sucrose solution $1 \%$ then all seeds were covered with bacterial vaccine carrier at rate $50 \mathrm{gm} / 1 \mathrm{~kg}$ seeds in sterilized Petri dishes under sterilized conditions to prevent any contamination (Al-Rajab, 2005).

Planting: The land of the biological experiment was divided well by ridges into 18 plots (experimental units). Each plot was $1 \times 1 \mathrm{~m}$. Width of each ridge was $25 \mathrm{~cm}$ to prevent contamination among the plots. Soil samples were taken to test the chemical and physical characters (Black, 1965 and Page et al, 1982), (Table 1). Randomized Complete Block Design (RCBD) was used with three replicates in this experiment under field conditions (Fig. 2). There was six treatments in each block as described in Table (3). There was two lines in each plot. Nitrogen and phosphorous fertilizers were added before planting as recommended to all plots. 15 sesame seeds with 
bacterial vaccine were planted in depth $3 \mathrm{~cm}$ in each pit 3 days after contamination the soil with fungi vaccine $\left(15^{\text {th }}\right.$, May 2009). There was 14 pits in each plot. The distance between pits was $15 \mathrm{~cm}$ and between lines was $50 \mathrm{~cm}$. Comparison treatment was left without contamination with fungi or bacterial vaccine or Dithen (No addition). Control treatment was left without contamination with bacterial vaccine or chemical fungicides, just with Fusarium fungi (AlAmery, 2003). Germination percentage was recorded three weeks after planting. Plants in each pit were thinned to 2 plants. On $5^{\text {th }}$ July 2009 (50 days after planting), leaf number per plant, branch number per plant and height of each plant were measured and calculated in each treatment. Fig. (2) shows general photo for the experiment site under field conditions, it was taken 21 days after planting. Table (1) shows some physical and chemical characters of the study soil before planting.

\begin{tabular}{|l|l|}
\hline Item & Unit \\
\hline $\mathrm{pH}$ & 7.6 \\
\hline $\mathrm{EC}$ & $3.4 \mathrm{dsms} / \mathrm{m}$ \\
\hline Soil density & $1.33 \mathrm{gm} / \mathrm{m}^{3}$ \\
\hline Ionic exchange capacity & $26 \%$ \\
\hline Silt & $37 \%$ \\
\hline Clay & $27 \%$ \\
\hline Sand & $36 \%$ \\
\hline Soil texture & Sandy loam \\
\hline Organic matter & 0.95 \\
\hline $\mathrm{N}$ & $2300 \mathrm{mg} / \mathrm{kg}$ \\
\hline $\mathrm{K}$ & $22 \mathrm{ppm}$ \\
\hline $\mathrm{P}$ & $11.8 \mathrm{ppm}$ \\
\hline
\end{tabular}

Measurements: 65 days after planting, many samples of leaves from each treatment were selected randomly and harvested to determine chlorophyll content $(a+b)$ (Witham et al., 1971). The following characters were calculated and measured 100 days after planting: Total number of leaf per plant, Height of plants $(\mathrm{cm})$, branches number per plant Leaf area per plant was measured as the following: $L A=L \times W$ $x 0.76$, when $L=$ length of leaf $(\mathrm{cm}), W=$ wide of leaf $\mathrm{cm}$ ) and $0.76=$ constant, According to Liang et al, (1973). All plants in each plot were harvested individually and carefully 112 days after planting (on $7^{\text {th }}$ September, 2009) to calculate the following: Pods number per plant, Grains number per pod per plant, total weight of 1000 grains, total yield of grains per plot. Percentage of nitrogen $(\mathrm{N})$, phosphorus $(\mathrm{P})$ and potassium $(\mathrm{K})$ in total dry weight of shoot were tested 65 days after planting, according to Dubis et al., (1956), Black (1965) and Sawhney and Randlhir (2000). While percentage of oil in the grains was tested and recorded according to Harbone (1973) and Sorenson (1974).

\section{RESULTS AND DISCUSSION:}

Results showed a clear effect for the ability of the two isolated bacteria in inhibition to fungi growth under incubator conditions cultured in KB media (Table, 2). Pseudomonas putida2 and Pseudomonas fluorescens3 gave high significant inhibition against fungi growth compared with control, Radiomil and Dithen treatments. In respect of Pseudomonas putida2 treatment, fungi growth reached $4.8 \mathrm{~mm}$ in diameter. And for Pseudomonas fluorescens3 treatment, the fungi growth reached $4.43 \mathrm{~mm}$. No growth in the mixture treatment of the two isolates together, while the mean of fungi growth in control treatment reached $82.7 \mathrm{~mm}$. In Dithen and Radiomil treatments the growth reached $29 \mathrm{~mm}$ and $33 \mathrm{~mm}$ respectively (Fig. 1).

Table 2: Comparison between the Biological activity of Pseudomonas sp. Bacteria with Dithen and Radiomil fungicide on diameter growth of Fusarium fungi which cultured in KB media under incubator conditions at $28 \mathrm{C}^{0}$ for seven days.

\begin{tabular}{|l|l|l|}
\hline Treatments & $\begin{array}{l}\text { Fusarium } \\
\text { growth } \\
\text { (mm) }\end{array}$ & \% inhibition \\
\hline $\begin{array}{l}\text { Pseudomonas putida 2 } \\
\text { + Fusarium }\end{array}$ & 4.80 & 94.2 \\
\hline $\begin{array}{l}\text { Pseudomonas } \\
\text { fluorescens 3+ } \\
\text { Fusarium }\end{array}$ & 4.43 & 94.6 \\
\hline $\begin{array}{l}\text { P. putida2 + P. } \\
\text { fluorescens 3+ } \\
\text { Fusarium }\end{array}$ & 0.0 & 100.0 \\
\hline $\begin{array}{l}\text { Dithen Fungicide + } \\
\text { Fusarium }\end{array}$ & 29.0 & 64.9 \\
\hline Radiomil + Fusarium & 33.0 & 60.1 \\
\hline $\begin{array}{l}\text { Control (Fusarium } \\
\text { only) }\end{array}$ & 82.7 & - \\
\hline LSD at 5\% & 11.2 & - \\
\hline Pseudomonas putida2 & scored inhibit \\
\hline
\end{tabular}

Pseudomonas putida2 scored inhibition in fungi growth by $94.2 \%$, while Pseudomonas fluorescens 3 scored inhibition in fungi growth by $94.6 \%$. Mixture of $P$. putida2 $+P$. fluorescens3 treatment scored inhibition in fungi growth by $100 \%$. Dithen and Radiomil treatments scored inhibition by $64.9 \%$ and $60.1 \%$ respectively compared with control treatment. Pseudomonas putida2 \& Pseudomonas fluorescens3 were significantly higher effect as Biocides on fungi growth more than Dithen and Radiomil fungicide treatment. However, Dithen treatment was more effective than Radiomil treatment in this study. This suppression in fungi growth, may be related to the siderophores and other metabolites compounds 
which produced by Pseudomonas isolates (Duijff et al, 1993; Dowling \& O,Gara, 1994). Most of Pseudomonas putida and Pseudomonas fluorescens and other species can produce phenozine antibiotic compound which inhibit growth of plant pathogenic fungi (Thomashow \& Weller, 1988). This is in agreement with many workers in this subject (Wood \& Pierson, 1996; Loper \& Henkles, 1999; Ganeshan \& Kumar, 2005). Moreover, For example, Pseudomonas chlororaphis pcl 1391 inhibited successfully growth of Fusarium oxysporium which caused root rot for tomato crop (Chin et al., 1998). This agrees with James \& Gutterson (1986) who used Pseudomonas fluorescens to inhibit Pythium ultimum fungi which caused damping of on cotton crop.

Table (4) and Figs. ( $2 \& 3$ ) show a clear effect for the two isolates on increasing branches number per plant, height of plant and leaf area per plant of sesame crop. Values of the above characters for Fusarium treatment (control) were 14.6 branch/plant, $53.3 \mathrm{~cm} /$ plant and $25.5 \mathrm{~cm}^{2} /$ plant respectively. While when we added bacterial vaccine of Pseudomonas putida2 to the seeds as a biocide to fungi treatments, values increased to $32.9 \mathrm{branch} / \mathrm{plant}, 105.7 \mathrm{~cm} / \mathrm{plant}$ and $41.2 \mathrm{~cm}^{2} /$ plant respectively. Addition bacteria vaccine of Pseudomonas fluorescens 3 to the seeds in fungi treatments increased values to 34.6 branch/plant, $106.7 \mathrm{~cm} /$ plant and $43.2 \mathrm{~cm}^{2} /$ plant respectively. Mixture of the two isolates together gave significant increases: 45.8 branch/plant, 151.7 $\mathrm{cm} /$ plant and $59.7 \mathrm{~cm}^{2} /$ plant respectively. Similar results were observed in respect of leaf number per plant (Table, 5). P. fluorescens3 treatment gave much higher values in increasing morphological characters against Fusarium fungi compared with $P$. putida2 treatment and control treatments (Fig. 3). This may be related to the variation in siderophores compounds which produced by them, and to its tolerance to field conditions. The high inhibition in growth characters in all fungi treatments may be related to the toxic compounds which produced from plant pathogenic fungi to inhibit activity of seed embryo. This agrees with Hameed \& Farhan (2007) who found that $P$. aureofaiciens and $P$. putida inhibited successfully growth of Rhizoctonia solani fungi on sorghum plant and with Chin et al (1998) who found that $P$. chlororaphis pcl 1391 inhibited successfully growth of Fusarium on tomato crop, and with Becker \& Cook (1988) with wheat crop.

Pods number per plant, grains number per pod per plant, total weight of 1000 grains and total yield of grains per plot for Fusarium treatment, were 44 pods/plant, 31.3 grains/pod, $0.94 \mathrm{gm} / 1000$ grain and $112.4 \mathrm{gm} /$ plot respectively, while when we added mixture of Pseudomonas fluorescens 3 and Pseudomonas putida2 to the sesame seeds as a biocide against fungi treatments, the values increased significantly to 146.7 pods/plant, 69.1 grains/pod, $2.92 \mathrm{gm} / 1000$ grain and $982.3 \mathrm{gm} / \mathrm{plot}$ respectively. Similar results were observed with vaccine of Pseudomonas putida2 and Pseudomonas fluorescens 3 treatments when they used separately (Tables, $5 \& 6$ ). This may be related to the ability of Pseudomonas $s p$ to produce promoter compounds (Deweger et al., 1987; Glick et al., 1997 and Abed et al., 2009) which can stimulate the growth and productivity of plants and inhibit growth of fungi Successfully.

Table (3) shows significant effect for Pseudomonas $s p$ as biocides in increasing chlorophyll content and levels of N, P and K in total dry weight of shoot (gm) per plant compared with control and fungi treatments. Fusarium treatment gave $0.85 \mathrm{mg} / \mathrm{gm}$, $1.52 \%, 0.07 \%$ and $0.98 \%$ respectively. While mixture of the two isolates together gave high significant results: $3.21 \mathrm{mg} / \mathrm{gm}, 4.18 \%, 0.44 \%$ and $3.87 \%$ respectively, this agrees with Abdel-Salam et al., (2007). Similar results were observed with vaccine of Pseudomonas putida2 and Pseudomonas fluorescens3 treatments when they used separately. Treatment of the mixture of the two isolates increased significantly percentage of oil in the sesame grains from $26.6 \%$ in control treatment to $56.2 \%$, and no addition treatment scored $46.3 \%$ (Table, 6). This agrees with Pierson and Weller (1994) in improving the growth of wheat. It is clear from results of this experiment, bacterial vaccine of the two isolates of Pseudomonas increased significantly the physiological characters per plant compared with control and other fungi treatments. Pseudomonas may protected sesame seeds from the toxic effect of fungi in contaminated soils with fungi by siderophores compounds which produced by Pseudomonas (Newman et al., 2001). Some compounds like siderophores and phenozine antibiotic produced from Pseudomonas species can inhibit growth of plant pathogenic fungi (Thomashow \& Weller, 1988; Kumar \& Dube, 1992; Dowling \& O'Gara, 1994; Wood \& Person, 1996; Duijff et al., 1999). The ability of Pseudomonas in increasing chlorophyll content in leaves may be related to the role of Pseudomonas in supplying the plants with some nutrient elements like N and P (Al-Rajab, 2005 and Hameed \& Farhan, 2007 
Table 3: Effects of Pseudomonas putida2 and pseudomonas fluorescens 3 on chlorophyll content and percentage of $N, P, K$ in dry weight of shoot of sesame crop planted in soil contaminated with Fusarium fungi under normal conditions.

\begin{tabular}{|l|l|l|l|l|}
\hline Treatments & $\begin{array}{l}\text { Chlorophyll } \\
\mathrm{a}+\mathrm{b} \\
(\mathrm{mg} / \mathrm{gm})\end{array}$ & $\% \mathrm{~N}$ & $\% \mathrm{P}$ & $\% \mathrm{~K}$ \\
\hline $\begin{array}{l}\text { Pseudomonas } \\
\text { putida 2 + } \\
\text { Fusarium }\end{array}$ & 2.29 & 3.82 & 0.35 & 2.23 \\
\hline $\begin{array}{l}\text { Pseudomonas } \\
\text { fluorescens 3+ } \\
\text { Fusarium }\end{array}$ & 2.17 & 3.06 & 0.23 & 3.11 \\
\hline $\begin{array}{l}\text { P. putida2 + P. } \\
\text { fluorescens 3+ } \\
\text { Fusarium }\end{array}$ & 3.21 & 4.18 & 0.44 & 3.87 \\
\hline $\begin{array}{l}\text { Dithen } \\
\text { Fungicide + } \\
\text { Fusarium }\end{array}$ & 1.78 & 2.70 & 0.27 & 3.06 \\
\hline No addition & 1.86 & 3.03 & 0.18 & 3.31 \\
\hline $\begin{array}{l}\text { Control } \\
\text { (Fusarium } \\
\text { only) }\end{array}$ & 0.85 & 1.77 & 0.11 & 1.34 \\
\hline LSD at 5\% & 0.81 & 1.52 & 0.07 & 0.98 \\
\hline
\end{tabular}

Table 4: Effects of Pseudomonas putida2 and pseudomonas fluorescens 3 on branch no./plant, height of plant $(\mathrm{cm})$ and leaf area/plant $\left(\mathrm{cm}^{2}\right)$ of sesame crop planted in soil contaminated with Fusarium fungi under normal conditions.

\begin{tabular}{|l|l|l|l|}
\hline Treatments & $\begin{array}{l}\text { Branch } \\
\text { no./plant }\end{array}$ & $\begin{array}{l}\text { Height of } \\
\text { plant (cm) }\end{array}$ & $\begin{array}{l}\text { Leaf } \\
\text { area/pla } \\
\text { nt }\left(\mathrm{cm}^{2}\right)\end{array}$ \\
\hline $\begin{array}{l}\text { Pseudomonas } \\
\text { putida 2 + } \\
\text { Fusarium }\end{array}$ & 32.9 & 105.7 & 41.2 \\
\hline $\begin{array}{l}\text { Pseudomonas } \\
\text { fluorescens 3+ } \\
\text { Fusarium }\end{array}$ & 34.6 & 106.7 & 43.2 \\
\hline $\begin{array}{l}\text { P. putida2 + P. } \\
\text { fluorescens 3+ } \\
\text { Fusarium }\end{array}$ & 45.8 & 151.7 & 59.7 \\
\hline $\begin{array}{l}\text { Dithen } \\
\text { Fungicide + } \\
\text { Fusarium }\end{array}$ & 23.6 & 104.0 & 41.2 \\
\hline No addition & 27.4 & 105.3 & 40.5 \\
\hline $\begin{array}{l}\text { Control } \\
\text { (Fusarium only) }\end{array}$ & 14.6 & 53.3 & 25.5 \\
\hline LSD at 5\% & 5.8 & 13.7 & 10.7 \\
\hline
\end{tabular}

Table 5: Effects of Pseudomonas putida2 and pseudomonas fluorescens 3 on leaf number per plant, Pods number per plant and Grains no./pod of sesame crop planted in soil contaminated with Fusarium fungi under normal conditions.

\begin{tabular}{|l|l|l|l|}
\hline Treatments & $\begin{array}{l}\text { Leaf } \\
\text { no./plant }\end{array}$ & $\begin{array}{l}\text { Pods } \\
\text { no./plant }\end{array}$ & $\begin{array}{l}\text { Grains } \\
\text { no./pod }\end{array}$ \\
\hline $\begin{array}{l}\text { Pseudomonas } \\
\text { putida 2 + } \\
\text { Fusarium }\end{array}$ & 297.3 & 101.3 & 51.2 \\
\hline $\begin{array}{l}\text { Pseudomonas } \\
\text { fluorescens 3+ } \\
\text { Fusarium }\end{array}$ & 374.7 & 106.0 & 52.8 \\
\hline $\begin{array}{l}\text { P. putida2 + P. } \\
\text { fluorescens 3+ } \\
\text { Fusarium }\end{array}$ & 428.3 & 146.7 & 69.1 \\
\hline $\begin{array}{l}\text { Dithen } \\
\text { Fungicide + } \\
\text { Fusarium }\end{array}$ & 269.3 & 88.3 & 47.0 \\
\hline No addition & 272.3 & 94.0 & 49.3 \\
\hline $\begin{array}{l}\text { Control } \\
\text { (Fusarium } \\
\text { only) }\end{array}$ & 162.7 & 44.0 & 31.3 \\
\hline LSD at 5\% & 77.82 & 17.3 & 8.0 \\
\hline
\end{tabular}

Table 6: Effects of Pseudomonas putida2 and pseudomonas fluorescens 3 on Weight of 1000 grain (gm), Total yield of grains per plot (gm) and percentage of Oil in grains of sesame crop planted in soil contaminated with Fusarium fungi under normal conditions.

\begin{tabular}{|l|l|l|l|}
\hline Treatments & $\begin{array}{l}\text { Weight of } \\
1000 \text { grain } \\
\text { (gm) }\end{array}$ & $\begin{array}{l}\text { Total yield } \\
\text { of grains } \\
\text { per plot } \\
\text { (gm) }\end{array}$ & $\begin{array}{l}\text { Oil in } \\
\text { grains }\end{array}$ \\
\hline $\begin{array}{l}\text { Pseudomonas } \\
\text { putida 2 + } \\
\text { Fusarium }\end{array}$ & 2.24 & 362.1 & 50.6 \\
\hline $\begin{array}{l}\text { Pseudomonas } \\
\text { fluorescens 3+ } \\
\text { Fusarium }\end{array}$ & 2.46 & 442.2 & 51.3 \\
\hline $\begin{array}{l}\text { P. putida2 + P. } \\
\text { fluorescens 3+ } \\
\text { Fusarium }\end{array}$ & 2.92 & 982.3 & 56.2 \\
\hline $\begin{array}{l}\text { Dithen } \\
\text { Fungicide + } \\
\text { Fusarium }\end{array}$ & 1.81 & 303.5 & 41.9 \\
\hline No addition & 2.29 & 352.4 & 46.3 \\
\hline $\begin{array}{l}\text { Control } \\
\text { (Fusarium } \\
\text { only) }\end{array}$ & 0.94 & 112.4 & 26.6 \\
\hline LSD at 5\% & 0.38 & 49.0 & 10.5 \\
\hline
\end{tabular}


Agric. Biol. J. N. Am., 2010, 1(5): 803-811

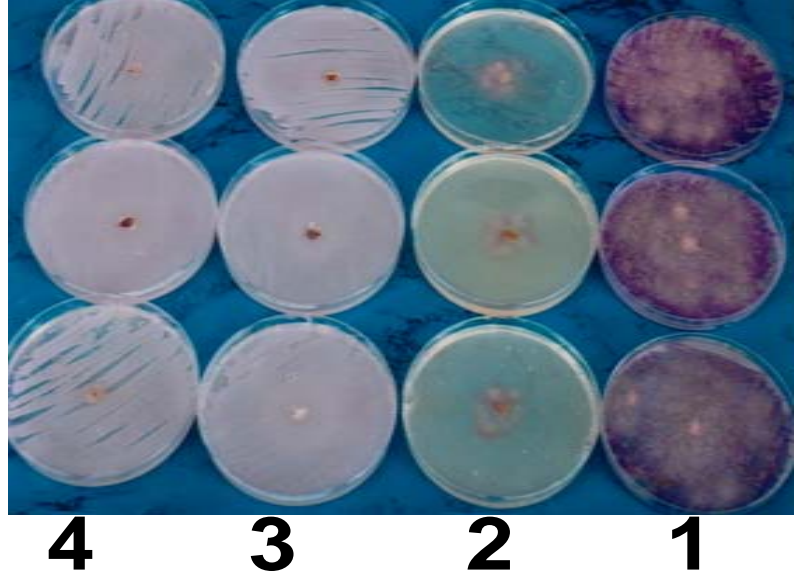

Fig.1 Shows the effects of pseudomonas

1. Control treatment (Fusarium ).

2. Dithen + Fusarium treatment

3. P. Putida $2+$ Fusarium treatment

4. P.fluorescens $3+$ Fusarium treatment

The clear increase in percentage of $\mathrm{N}, \mathrm{P}, \mathrm{K}$ and oil by Pseudomonas treatments may be related to the ability of Pseudomonas $s p$ to produce promoter compounds like indole acetic acid (IAA), cytokinins and polysaccharides (Deweger et al., 1987 and Glick et al., 1997, Abed et al., 2009), which can stimulate the growth of plants. Dithen treatment was applied once to the experiment soil at planting time but did not give clear effect as expected, this may be related to continuous irrigation water which may diluted the concentration of Dithen chemical against fungi. It is clear from the primary results of this experiment, bacterial Wheat bran powder as a carrier succeeded in this experiment under normal conditions to keep the bacterial cells in active way during the period of experiment.

\section{CONCLUSIONS}

It is difficult to sterilize soil in large area by chemicals and so difficult to kill fungi inside the plant. Use the pesticide chemicals in Agriculture cause contamination problems to the Ecological Resources. Biological control is one from many methods to protect crops and keep the Ecological Resources in the safe side. These two isolates have a dual effect as biocides (Biocontrol) and biofertilizers. There was a clear effect in improving the quantity and quality characters of sesame crop under field conditions. Pseudomonas $s p$ is not specific against one group of fungi. This effect encourages using bacterial vaccines as Biocides in the applied field to protect plants from fungi diseases in wide range.

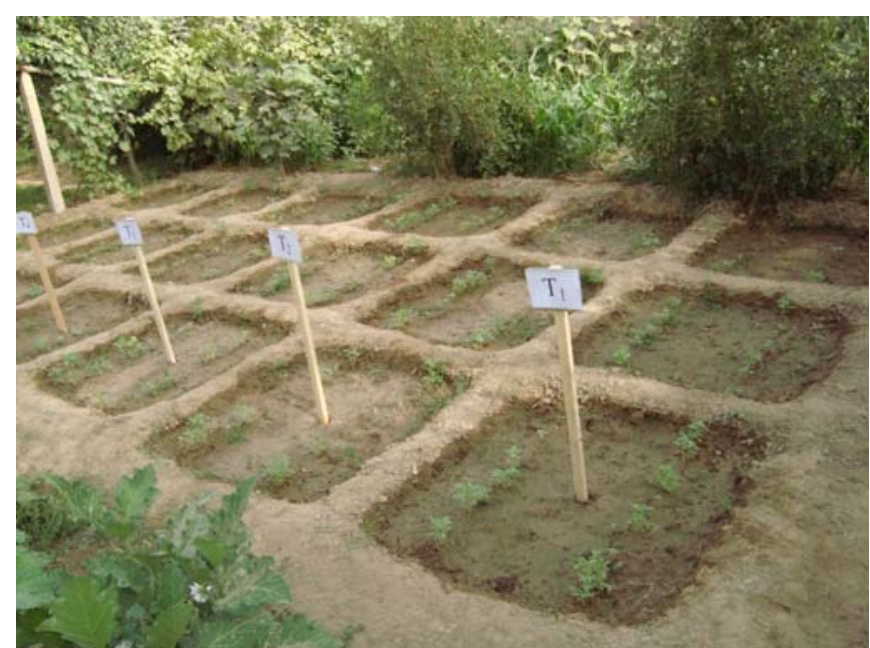

Fig. 2 General photo for the whole experiment was taken 21 days after planting.

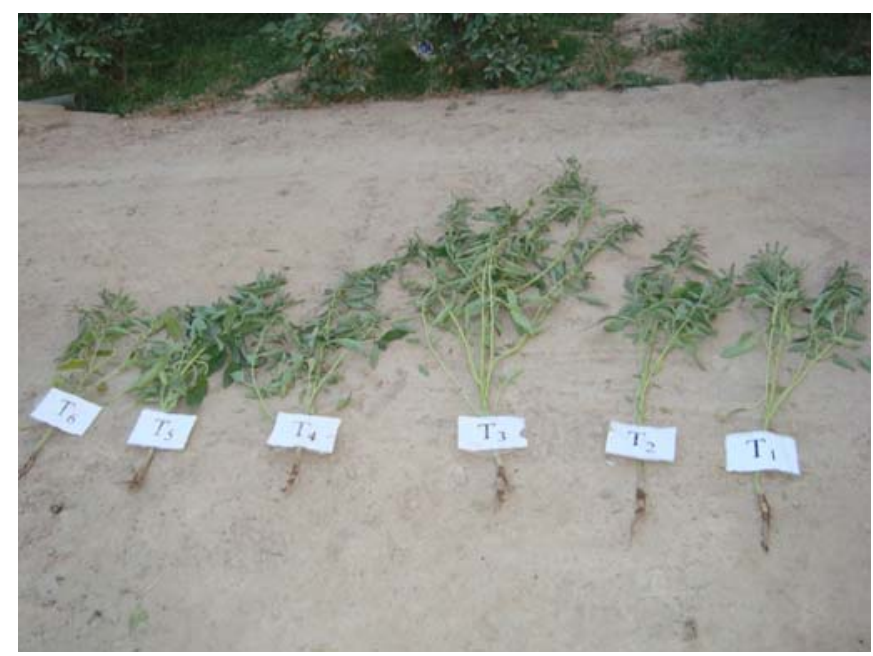

Fig. 3 shows the differences between the six treatments 100 days after planting. T1=Pp2, T2=Pf3, T3=Pp2+Pf3, T4=Dithen, T5=No addition, pT6= Fusarium only

\section{ACKNOWLEDGEMENT}

It is fair from research team of this project to thank Arab Science and Technology Foundation (ASTF), United Arab Emirates for its great grant and supporting this research and others in Iraq.

\section{REFERENCES}

Agrios, G.N. (1988). Plant pathology, $3^{\text {rd }}$ edition, Academic press, San Diego, California, USA pp. 803

Abed, I.A., Farhan, H.N. and Hommod, J.S. (2009). Bacterial Indole Acetic Acid (IAA) Production by Using Local Media and Test its efficiency on soya bean plant. Anbar Univ. J. for Pure Sciences, 1(3), p 10-18 
Abdel-Salam, M.S., Abd-El-Halim, M.M., and El-Hamshary, O. I. M. (2007). Improvement of Pseudomonas Antagonism Against Fusarium oxysporium through protoplast Fusion: I-Fusant induction. Research J. of Cell and Molecular Biology, 1(1): 37-41

Al-Amery, M.A.F. (2003) Isolation, identification and evaluation the efficiency of $P$. putida as Biological control against some pathogenic fungi. PhD. Thesis, College of Sciences, Al-Anbar University, Iraq.

Al-Rajab, A.T.H. (2005) Isolation and identification of P. aureofaiciens and $\mathrm{P}$. chlororaphis from depositional soil in Al-Anbar Governorate and efficiency evaluation of P. aureofaiciens a Biocontrol and Biofertilizers, MSc. Thesis, College of Sciences, Al-Anbar University, Iraq.

Amer, G.A. and Utkhed, R. S. (2000). Development of formulation of biological agents for management of root rot of lettuce and cucumber. Can J. Microbiol. 46: 809816

Becker, J.O. and Cook, R.J. (1988) Role of siderophores in suppression of Pythium species and production of increased growth response of wheat by $P$. fluorescent. Phytopathology 78: 778-782

Benani, F.; Bassis, E.; Benohaabane, M. and Digat, B. (1994) Growth promoting and biocontrol of verticillium dahlae of tomato with pseudomonas. Fifth Arab Congress of Plant Protection $27^{\text {th }} \mathrm{Nov}-2^{\text {nd }}$ Dec.

Black, C.A. (1965). Methods of soil analysis. Part 2 Chemical and Micro properties. Mn. Soc. Agron. Inc. Pub. Madison, Wisconsin, USA.

Bowyer, P. (1999). Plant disease caused by fungi: phytopathogeneticity in: Molecular Fungal Biology, (RP Oliver, M Schweizer), Cambridge University Press, Cambridge Chapman and Hall, London, UK.

Burr, T.J. Schroth, M.N. and Suslow, T. (1978). Increased potato yields by treatment of seed pieces with specific strains of $P$. fluorescens and putida. Phytopathology, $68,1377-1383$

Chin, A.; Woeng, T.F.C; Bloemberg, G.V; van der Bji, A. van der Driftkm, G.M. Shripsema, J; Kroon, B. Scheffer, R.J.; Keel, C; Baker, P.A.H.M. and Ticky, H.T. (1998) Biocontrol by phenozine-1- carboxyamide producing $P$. Chlororaphis pcl 1391 of tomato root rot caused by Fusarium oxysporum. Plant Microb. Intract. 11, 10691077

Clark, F.E. (1965) Agar plate method for total microbial count. C.F. Black method of soil analysis Part2. Publisher Madison, Wisconsin, USA. pp :1572

Cowan, S.T. (1977). Cowan and Steels manual for the identification medical bacteria $2^{\text {nd }}$ ed. Cambridge University Press, Cambridge.

Deluz, WC., Bergstrom, GC. And Stock Well CA (1998). Seed applied bioprotectants for control of seed borne
Pyrenophora tricic-repentis and agronomic enhancement of wheat. Can. J. of Plant Pathology. Rev. Can. Phytopathology. 20 (4) 384-386

Deweger, L.L.A., Jann, K., and Lugtenberg, (1987). Lip polysaccharide of Pseudomonas sp. Yjat Stimulate Plant Growth Composition and Testing for Strain Identification. J. Bact. 1669: 1441-1446 .

Dowling, D.N. and O'Gara, F. (1994) Metabolites of Pseudomonas involved in the Biocontrol of plant disease. Trends Biotech. 21: 133-141

Dubis, M.; Gilles, K.A.; Hamilton, J.K.; Rebers, D.A. and Smith, F. (1956). Colorimetric method for determination for sugar and related substance. Anal. Chem. 28: 350360

Duijff, B.J.; Meijer, J.W.; Bakker PAHM and Schippers, B. (1993). Siderophores-mediated competition for iron and induced resistance in the suppression of Fusarium wilt of carnation by fluorescent pseudomonas sp. Netherlands Journal of Plant Pathology. 99: 277-289

Duijff, B.J.; Recorbet, G.; Bakker, PAHM; Loper, J.E. and Lemanceau, P. (1999) Microbial antagonism at the root levels is involved in the suppression of Fusarium oxysporium FO47 and Pseudomonas putida WCS358. Phytopathology 89: 1073-1079

Gamliel, A. and Katan, J. (1993). Influence of seed and root exudates of fluorescent pseudomonas and fungi polarized soil. Phytopathology 82: 320-327

Ganeshan, G. and Kumar, A.M. (2005) Pseudomonas fluorescens, a potential bacterial antagonist to control plant diseases. Journal of Plant Interactions. V1 (3): 123-134.

Georgakpoulos, D.G.; Fiddaman, P.; Leifert, C. and Malathrakis, N.E. (2002). Biocontrol of cucumber and sugar beet damping-off caused by Pythium ultimum with bacterial and fungal antagonists. J. Appl. Microbiol. 92: 1078-1086

Glick, B.R., Penrose, D.M. and Li, J.A. (1997). A model for the lowering plant ethylene concentration by plant growth promoting bacteria. J. Theor. Biol. 190: 63-68

Hadedorn, C.; Gould, W.D. and Bardinelli, T.R. (1993) Field evaluations of bacterial inoculants to control seedlings disease pathogens on cotton. Plant Disease 77: 278282

Hameed, A. T. and Farhan, H.N. (2007) Effect of Pseudomonas aureofaiciens \& Pseudomonas putida on growth of sorghum biocolor and protect them from infection of Rhizoctonia solani fungi. Al-Anbar University Journal for Pure Science. 1(3): 8-16

Harbone, J.B. (1973) Photochemical methods. Halsted Press, John Wiley and Sons, New York, p 278

Hossain M. (1987). The antagonistic effect of fluorescent Pseudomonas sp. on plant growth and the control of 
soft rot and black leg of potato. Plant Pathogenic Bacteria, Martinus Nijhoff Pub. U.S.A.

James, D.W., \& Gutterson, N. I. (1986) Multiple antibiotics produced by $P$. fluorescens HV37a and their differential regulation by glucose. Appl. Environ. Microbiol. 52: 1183-1189

Kloepper, J.W. and Scroth, M.N. (1981). Relationships of in vitro antibiosis of plant growth promoting rhizobacteria to plant growth and the displacement of root micro flora. Phyto. 71: 1020-1024

Kloepper, J.W., Mclnory, J.A. and Bowen, K.I. (1992). Comparative identification by fatty acid analysis of soil rhizosphere and geocarposphere bacteria of peanut (Arachis hypogaea L.). Plant Soil, 139: 85-90

Kumar, B.S.D. \& Dube, H.C. (1992) Seed bacterization with a fluorescent Pseudomonas for enhanced plant growth yield and disease control. Soil Biol. Bachem. 24: 539542

Liang, G.H.; Chu, C.C.; Reddy, N.S.; Lin, S.S. and Dayton, A.D. (1973). Leaf, blade areas of grain sorghum varieties and hybrid. Agron. J., 65 : 456-459

Loper, J.E. (1988). Role of fluorescent siderophores production in Biological control of Pythium ultimum by Pseudomonas fluorescens strain. Phytopathology, 78: 166-172

Loper, J.E. and Henkels, M.D. (1999). Utilization of heterologus siderophores enhances levels of iron available to $\mathrm{P}$. putida in the Rhizosphere. Appl. And Environ. Microbiology. 65(12): 5357-5363

Lottman, J. Heuer, H. Devries, J. Mahn, A. During, K. Wackernagel, W., Small, K. and Berg, G. (2000) Establishment of introduced antagonistic bacteria in the Rhizosphere of transgenic potatoes and their effect on the bacterial community. FEMS Microbiol. Ecol. 33 (1) 41-49

Newman, M.A., Dow, J.M., and Daniels, M.J. (2001). Bacterial lip polysaccharide and plant pathogen interaction. Eur. J. Plant Pathol. 107: 95-102

Nwaga, D.; Fankem, H.; Essono Obougou, G.; Ngonkot, L. and Randrianangaly, J.S. (2007) Pseudomonas and symbiotic micro-organisms as biocontrol agents against fungal disease caused by Pythium aphanidermatum. African Journal of Biotechnology. 6(3): 190-197

Page, A. L., Miller, R.H. and Keeny, D.R. (1982) Methods of soil analysis, Part 2, ${ }^{2 n d}$, Madison, Wisconsin, USA, p 1159.

Pierson, E. A. and Weller, D. M. (1994). Use of mixture of fluorescent Pseudomonas to suppress take-all and improve the growth of wheat. Phytopathol. 48: 940-947

Sawhney, S.K. and Randlhir, R. (2000). Introductory Practical Biochemistry. Norsa Publishing House. New Delhi.

Schroth, M.V. and Hancook, J.G. (1982). Disease suppressive soil and root colonizing bacteria. Science, 216, 1376-1381

Smith, K.P. and Goodman, R.M. (1999) Host variation for interaction with beneficial plant associated microbes. Ann. Rev Phytopathl. 378: 473-491

Sorenson, S.P. (1974). The analysis of foods. John and Sons, New York.

Thomashow, L.S. and Weller, D. M. (1988) Role of Phenazozine antibiotic fro P. fluorescens in biological control of Gaemannomyces graminis var tritic. J. Bacteriol. 170 : 3499-3508

Weller, D.M. (1988) Biological control of soil borne plant pathogens in the Rhizosphere with bacteria. Ann. Rev. Phytopathology. 26: 378-407

Weller, D.M. and Cook, R.J. (1986) Increased growth of wheat by seed treatment with fluorescent pseudomonas and implication of Pythium control. Can. J. Plant Pathol. 8: $328-334$

Witham, F. H.; David, F.; Robert; and Devlin, M. (1971). Experiments in plant physiology. Litton Education Publishing, INC New York.

Wood, D.W. \& Person, L. (1996) The phzlgen of $P$. aureofaciens $30-84$ is responsible for a diffusible signal required or phenozine antibiotic production. Gene, 128: 81-86. 